\title{
The Impact of Terrorism on Nigerian Business Environment (Case Study of Emab Business Plaza Wuse II Abuja)
}

\author{
Article by Chinenye Cynthia Kalu \\ School of Management Science, Texila American University, Guyana \\ E-mail: chinnykalu77@gmail.com
}

\begin{abstract}
Terrorism has impacted levels of society across the world community, one of those levels is the business environment. Terrorism aim is nothing but to create a permanent state of terror, hatred and mistrust generalized in the population. Terrorism will directly impact a country's ability to attract and maintain business development and investment. One of the key aspects of terrorism is the psychological impact on a populace. The uncertainty of the attack brings human fear. This paper examines the impact of terrorism on business environment in Nigeria with a case study of the Emab Business Plaza Wuse II Abuja. The study used questionnaire and oral interview as research instrument. Data were obtained, presented and analysed with simple percentages and frequency distribution tables. The questionnaire was administered to Business Owners, Customers, Employees and Government regulators. The study concludes that there is a significant impact of Terrorism on business environment. It is recommended that the Business Environment should be able to cope with terrorism by Putting up a secured and structured security network, to prepare for quick intervention after an attack, to have decentralized decision making system, to plan for the rapid reconstruction of the physical capital, to have a strategy for rapid reconstruction of human capital.
\end{abstract}

Keywords: Terrorism, Business, Business Environment and Business Development.

\section{Introduction}

Terrorism is defined in the UK Terrorism Act 2000 as "the use or threat of violence for the purpose of advancing a political, religious or ideological cause”. Terrorism is actually planned and intended to achieve particular goals. It is a rationally employed, specifically selected tactic and is not a random act.

"Terrorist weaken industry and society through their manipulation of economic systems components- companies, non- profits, labour, capital and technology against their target” (Alexander, 2004; 4). Terrorist direct their attacks against business far more than any other target. The most common type of event is bombing, armed attack, kidnapping, arson and vandalism.

A general knowledge of the prevalent models of terrorist organization lead to a better understanding of their capabilities. Terrorist group may form only one cell or may form many cells that operates locally or internationally. The number of cells and their composition depends on the size of the terrorist group. Terrorism is continually changing, it remains the calculated use of unlawful violence or threat of unlawful violence to inculcate fear. It is rapidly becoming the predominant strategic toll of our adversaries. It evolves into the principal irregular warfare strategy of the $21^{\text {st }}$ century. It is adapting to the world sociopolitical environment, some of the changes facilitates the abilities of terrorist to procure funding, operates and develop new capabilities.

Terrorist are improving their sophistication and abilities in virtually all aspects of their operations and support. The aggressive use of the modern technology for information management, communication and intelligence has increased the efficiency of terrorist activities. Weapon technology has become more available and the purchasing power of terrorist organization is on the rise. 
Texila International Journal of Management

Volume 2, Issue 2, Dec 2016

The ready availability of both technology and the trained personnel to operate it for any client with sufficient cash allows the well-funded terrorist to equal or exceed the sophisticated of governmental counter- measures. Terrorism took on a different more global meaning after the terror attacks in New York on September 11, 2001.

Nigeria is one of the highly populated country in the West Africa and it strive in its involvement in commercial activities across the globe.

Business Environment is all the internal and external factors that affects how company functions including employees, customers, management, supply and demand and business regulations. These internal and external factors can influence each other and work together to affects the outcome of the business. It is also how well the business meet its customers' expectations.

A Plaza is a public square, market place or similar open space in a built up area. It is also known as shopping centers. Business Plaza is a market place or similar open space in a built up area where different commercial activity takes place. Since the $20^{\text {th }}$ century business men have moved from the local business setting to a more modernized and structured business setting where all business activities are conveniently located in a building for easy access to the masses and for easy transactions in Nigeria most of the commercial activities are done in business plaza, people traffic those places to carry out various business activity.

Emab business plaza is located in the capital city of Nigeria and it is one of the busy commercial center which business ranges from phone repairs, sales of electronics, household and office equipment, banking activities are carried out. Outside the plaza are all kinds of street vendors.

The purpose of this research work is to study the impact of terrorism as it affects the business and its relationship with its customers, demand, supply employee, business regulators and management focusing on the incident of terrorism in Emab plaza wuse II in Abuja, Nigeria in 2014. The study will be looking at the reaction of the customers, employees, management, business regulators to terrorism.

\section{Theoretical framework}

Terrorism can be defined as the systematic threat or use of violence, often across natural borders to attain a political goal or communicate a political message through fear, coercion or intimidation of non- combatant persons or the general public (Alexander et al 1979).

\section{Stages of terrorism}

In the early years of the $20^{\text {th }}$ century nationalism and revolutionary political ideologies were the principle and developmental force acting upon terrorism. When the treaty of Versailles changed the European map after the world I, it gives opportunity to selfdetermination for nationalities and ethnic groups which encourages minorities and ethnicities not receiving recognition to campaign for independence or autonomy.

Arab Nationalities felt betrayed when the French and the British were given authority over their land and the Zionist immigration into Palestine.

Since second war II, terrorism has increased its effects into component of conflict. It has also proven to be a significant tool of diplomacy and international power for states inclined to use it.

In the new age of terrorism, it has taken a different shape in order to enforce it activity and to embark its violence in a way that every part of the economy will be affected. They innovate, exploit new technology, learn from one another, initiate successful tactics, produce manuals of instruction based on experience, debate tactics targets, limits on violence and justify their actions with doctrines and theories.

It has become bloodier, developed new financial resources so that they are less dependent on state sponsors, they have evolved new models of organization, they can now wage global campaigns and they have effectively exploited new communications technologies. 
Some of the terrorists have moved beyond tactics to strategy although none of them have achieved their stated long range goals. They have not done many of the things we worried about years ago, our worst fears have not been realized on the other hand no amount of analysis can cover every conceivable terrorist scenario at every form of attack. The future like the past will probably bring surprises and shocks.

\section{Cost of terrorism}

The cost of terrorism to the world was calculated in the past two years as highest since 2001 and it is still in the increase.

In Nigeria it is estimated that terrorism caused direct investment flows to drop in the past six years. However, a number of factors influence the cost of terrorism in a country. The diverse nature of terrorism, the economic resilience of an economy and the security levels all play a role. The economic impact of terrorism varies between countries.

\section{Who is affected}

- The survivors of past traumatic events.

- People who personally witnesses or were victims of the terrorist attack.

- People who experience traumatisation from learning of relatives, friends and acquaintances that were subject to the violence.

- People may enter a state of acute stress.

- Recurring thoughts of the incident, becoming afraid of everything not leaving the house or self-isolation, stopping usual functions, no longer maintaining daily routines, tremendous sense of loss, reluctant to express feelings.

- In the business it can kill a customer or a potential customer.

- It can destroys the physical plant and machinery used to run any business.

- It causes psychological long term damage.

- It has potential to cause political instability.

\section{Business and its environment}

Business is basically an economic activity, its primary objectives are economic in nature. The main economic objectives of business are as follows:

1. Earning profits

2. Creating customers

3. Innovation.

4. It can't exist in a vacuum

5. It can't survive and grow without the support of society

6. It has to supply desired goods at reasonable price and provides social warfare.

In achieving the economic and social objectives of business the well-being of the labour is considered by developing human resources and having a participative management.

Every business can be limited by unexpected and unanticipated events.

Business Environment means all of the internal and external factors that affects hoe company functions including employees, customers, management, demand, supply and the business regulations.

External factors are the institutions that are beyond the control of the business and affects the functioning of the business enterprise. These includes customers, competitors, suppliers, government and the social, political, legal and the technological factors.

Business environment is dynamic in nature and it differs from place to place, region to region and country to country. Political and economic condition in one country differ from another country.

\section{Components of business environment}

Internal Environment: It include all those factors that affects business which are present within the business itself. These factors are usually under the control of business which 
Texila International Journal of Management

Volume 2, Issue 2, Dec 2016

includes ; Objectives of the business, policies of the business, production capacity, production methods, managerial information system, participation in management, composition of board of directors, managerial attitude, organizational structure and features of human resources.

External Environment: It includes all the factors which influence business and exist outside the business. Business has no control over these factors. These environment is divided into micro and macro environment.

These internal and external factors are:

Customer: They are the recipient of a good, service, product or an idea obtained from a seller, vendor or supplier through a financial transaction or exchange for money or some valuable consideration. They have the ability to influence the business.

Suppliers: It is a party that supplies goods and services. It is also known as vendor. They have the ability to influence the business.

Competitors: Competing firms can influence business in a number of ways.

Employees: these are the labour employed in order to render the services to the customer and also those that produce the product and ensures it get to the final consumer.

Management: These are the people that makes decisions and make sure different strategies are implemented by other factors to ensure the objectives of the business are being realize.

\section{Methodology}

During the fieldwork random sampling and structural questionnaires were used for collecting the primary data from one hundred (100) respondents which includes employees, management, suppliers, customers and government agencies.

These questionnaires were distributed and the response rate was $90 \%$.

\section{Findings}

The information from the questions administered with the references to how terrorism has influence their relations or behavior to the business in the location Emab Plaza.

Table 1. Does the terrorist attack causes reduction in the number of the staff

\begin{tabular}{|l|l|l|}
\hline Response & No. of Respondent & Percentage \\
\hline Strongly Agreed & 80 & $88.9 \%$ \\
\hline Strongly Disagreed & 10 & $11.1 \%$ \\
\hline Total & 90 & $100 \%$ \\
\hline
\end{tabular}

In the above table $88.9 \%$ agree that the attack causes reduction in the number of staff while $11.1 \%$ disagree.

Table 2. Does the terrorist affects the performance of the employee

\begin{tabular}{|l|l|l|}
\hline Response & No. of Respondent & Percentage \\
\hline Strongly Agreed & 75 & $83.3 \%$ \\
\hline Strongly Disagreed & 15 & $16.7 \%$ \\
\hline Total & 90 & $100 \%$ \\
\hline
\end{tabular}

In the above table $83.3 \%$ agree that there is reduction in the performance of the employee while $16.7 \%$ disagree 
Table 3. Does the terrorist attack affects some of the management decision

\begin{tabular}{|l|l|l|}
\hline Response & No. of Respondent & Percentage \\
\hline Strongly Agreed & 70 & $77.8 \%$ \\
\hline Strongly Disagreed & 20 & $22.2 \%$ \\
\hline Total & 90 & $100 \%$ \\
\hline
\end{tabular}

In the above table $77.8 \%$ agree that the attack causes change in some of the management decisions while $22.2 \%$ disagree.

Table 4. Does the terrorist attack causes rapid decrease in customer turn over

\begin{tabular}{|l|l|l|}
\hline Response & No. of Respondent & Percentage \\
\hline Strongly Agreed & 85 & $94.4 \%$ \\
\hline Strongly Disagreed & 5 & $5.6 \%$ \\
\hline Total & 90 & $100 \%$ \\
\hline & & \\
\hline
\end{tabular}

In the above table $94.4 \%$ agreed that the attack causes decrease in customer turnover while $5.6 \%$ disagree.

Table 5. Does the terrorist attack causes reduction of the number of occupants.

\begin{tabular}{|l|l|l|}
\hline Response & No. of Respondent & Percentage \\
\hline Strongly Agreed & 75 & $83.3 \%$ \\
\hline Strongly Disagreed & 15 & $16.7 \%$ \\
\hline Total & 90 & $100 \%$ \\
\hline
\end{tabular}

In the above table $83.3 \%$ agreed that the attack causes reduction of the number of occupants in the plaza while $16.7 \%$ disagree.

Table 6. Does the terrorist attack affects the availability of products and services

\begin{tabular}{|l|l|l|}
\hline Response & No. of Respondent & Percentage \\
\hline Strongly Agreed & 65 & $72.2 \%$ \\
\hline Strongly Disagreed & 25 & $27.8 \%$ \\
\hline Total & 90 & $100 \%$ \\
\hline
\end{tabular}

In the table above $72.2 \%$ agreed that the attack influences the availability of the product and services within the plaza while $27.8 \%$ disagreed.

Table 7. Does the terrorist attack affects the returns the business makes to the Government

\begin{tabular}{|l|l|l|}
\hline Response & No. of Respondent & Percentage \\
\hline Strongly Agreed & 85 & $94.4 \%$ \\
\hline Strongly Disagreed & 5 & $5.6 \%$ \\
\hline Total & 90 & $100 \%$ \\
\hline
\end{tabular}

In the above table $94.4 \%$ agreed that the returns the business makes to the government is been influence by the attack while $5.6 \%$ disagree.

Table 8. Does the terrorist attacks affect the cost of running the business plaza

\begin{tabular}{|l|l|l|}
\hline Response & No. of Respondent & Percentage \\
\hline Strongly Agreed & 80 & $88.9 \%$ \\
\hline Strongly Disagreed & 10 & $11.1 \%$ \\
\hline Total & 90 & $100 \%$ \\
\hline
\end{tabular}

The table above shows that $88.9 \%$ agreed the attack influence the cost of running the business plaza while $11.1 \%$ disagree. 
Texila International Journal of Management

Volume 2, Issue 2, Dec 2016

Table 9. Does the terrorist attacks affect the cost of the rental space of the business plaza

\begin{tabular}{|l|l|l|}
\hline Response & $\begin{array}{l}\text { No. of } \\
\text { Respondent }\end{array}$ & Percentage \\
\hline Strongly Agreed & 85 & $94.4 \%$ \\
\hline Strongly Disagreed & 5 & $5.6 \%$ \\
\hline Total & 90 & $100 \%$ \\
\hline & & \\
\hline
\end{tabular}

The table above shows that $94.4 \%$ agreed strongly that the cost of the rent of the office space is influenced by the effect of the attack while $5.6 \%$ disagree.

Table 10. Does the terrorist attacks affect the cost of services and product in the business plaza

\begin{tabular}{|l|l|l|}
\hline Response & No. of Respondent & Percentage \\
\hline Strongly Agreed & 80 & $88.9 \%$ \\
\hline Strongly Disagreed & 10 & $11.1 \%$ \\
\hline Total & 90 & $100 \%$ \\
\hline
\end{tabular}

In the above table $88.9 \%$ are in the opinion that the cost of the services in the business plaza increases due to the influence of the attack while $11.1 \%$ disagree.

\section{Discussion}

From the results of the study and the findings in the table, it is clear from the opinion of respondents that terrorism has a significant influence on the relationship the business has with its environmental factors.

1. Reduction of number of staff: The attack may leads to death of some staff working in the organization which will reduce the number of staff and the trauma may affect the other staff and they may be afraid to continue their job.

2. Performance of the employee: The attack may affect the performance of the employee they will not be focus on their job but rather starts to have conflicts of interest.

3. Change in management decision: The attack may cause death of a key management staff that will cause change in management decision and strategies that may affect the success of the business.

4. Decrease in customer turnover: The attack causes trauma and instill fear in people and these will affect the turnover of the customer.

5. Number of Occupancy: Some business owners occupying the plaza or within the location of the attack will want to quickly relocate to a safer place.

6. Tax Reduction: The returns the business makes to the government in the form of tax will be affected as business activities reduces.

7. Availability of products: Vendors are discouraged inform making supplies which will in turn affects the availability of the products.

8. Increase in cost: in order to increase the level of security in the premises the cost of installing technological security system will increase the cost of managing the plaza.

9. Increase in rental space: As the management install modern security system, the cost will be added to the cost of the rent of each office space.

10. High cost of commodity: When the cost is spread to the products and services it in turn cost high rate of services offered within the business premises.

\section{Summary, conclusion and recommendation}

This study has investigated into the impact of terrorism on the Nigerian business environment focusing on the case study of the Emab Plaza Wuse II Abuja. In the course of the research introduction and the review of related literature was carried out. Questionnaires were designed and distributed to relevant respondent which includes employees, management, customers, Government regulators and vendors. Data were analyzed by tabulation with the use of simple percentages.

The result proved that there is significant impact terrorism has on business environment. 


\section{Recommendation}

In view of the findings from the study, terrorism is an unforeseen event that is not planned. However, business should have a risk plan through providing insurance which can help reduce the impact of the event when it occurs to businesses.

When business is insured the impact will not be much on the factors business environment.

Government should assist in providing security when business are secured the economy is also secured.

\section{Conclusion}

In conclusion, based on the data collected and its analysis terrorism have significant influence on the business environment through reduction of the number of staff and it affects their performance. It causes change in management and the management decision. It affects the turnover of customer, vendors and increases the cost of managing the business premises which in turn affects the cost of the rent and cost of commodity. It also affects the return the business makes to the government.

\section{Refernces}

[1]. Alexander, Dean C. 2004 Business conflict Terrorism: Risks and Response. The university of Wisconsin press.

[2]. Alexander, Yonah et al (1979) Terrorism: Theory and Practice. Boulder, Co. Westview press.

[3]. www.express co.uk/news/world/693528/terrorism.

[4]. www.weforum.org/agenda/what-is-the-economic-impact-of- terrorism.

[5]. Blomberg S.B Gregory D.Hess, Orphandes,A (2004) " the macroeconomics consequences of Terrorism” Journal of monetary economics, volume 51.

[6]. Effect of terrorism on international business in Nigeria, Odimeji, moruff Sanjo (Ph.d) Oresanwo, Adeniyi Marcus. Michael Otedo College of Primary Education Nigeria. Department of Economics.

[7]. Terrorism and international business, working paper Gary Night, college of business, Florida state university. 